\title{
Happiness in View of Aristotle and Avicenna
}

\author{
Hojjatollah Raftari
}

\begin{abstract}
Euphoria [alternative terms: happiness, felicity, prosperity, success, is an important concept in the philosophy of ethics. It is, therefore, necessary to know what euphoria is. Is it a pleasure, a sense of wisdom, a science, goodness, or else, something beyond these? All humans are seeking euphoria, but they have their doubts about the weakness of euphoria. Human beings do not know what it is. However, they do know that euphoria is something consistent with man's creation and his ultimate goal. Accordingly, a euphoric or prosperous person is someone who is on his way towards God and the absolute perfection. Avicenna classifies euphoria into two parts: corporeal and spiritual. He thinks that the spiritual euphoria is original. He maintains that absolute euphoria cannot be obtained in this world; Aristotle, however, believes that euphoria can be obtained in this world. Both Avicenna and Aristotle state that euphoria has different stages, and that the prosperous man moves towards the pure reason, or the pure thinking, that is, God. Since God is infinite, the movement may continue up to infinity. This way, man achieves the true euphoria.
\end{abstract}

Index Terms-Euphoria (alternative terms are happiness, felicity, prosperity, success, etc.), supreme euphoria, virtue, Aristotle, Avicenna.

\section{INTRODUCTION}

One of the important concepts in ethics and in the philosophy of ethics is euphoria, or prosperity, or happiness, or success, as some thinkers tend to use these alternative terms. Euphoria, which is a New Latin word taken from the Greek word euphoros , meaning originally healthy, from eu[ good] and pherein, [ to bear] , has long been a fundamental component in ethics and the philosophy of ethics. Different schools of thought have incorporated the concept in their ethical systems. It has received a special attention from various systems of thinking, both in the west and in the East.

In this study, we have discussed the viewpoints to Aristotle as a western philosopher, and the viewpoints of Mulla Sadra as a philosopher from the East, since both of these philosophers are considered classical thinkers in the field of philosophy. In a comparative study, we have addressed these two viewpoints on the euphoria, or as some writers call it, the prosperity.

\section{Procedure for PAPER SUbMission}

When In Zoroastrianism, mankind is considered as a creature created by Goodnesss,. He has been, therefore, shaped into a good creature by the hands of his creator. $\mathrm{He}$ has been vested with freedom and power of choose, $\mathrm{He}$

Manuscript received May 7, 2014; revised July 7, 2014.

Islamic Azad university-Khoramabad Branch-Khoramabad-Lorestan state-Iran (e-mail: raftari_h@yahoo.com). has the power of choosing any path he desires.

According to Judaism and Christianity, mankind is able to choose between good and evil, He has the option to be godly or ungodly, and his salvation depends on this freedom. [the Holy Bible, the old testament, the new testament].

In the Greek philosophy, Socrates was interested in the human virtues and the bliss for humans. Aristotle says that Socrates addressed the ethical matters and the ethical virtues [1], [2].

Among the sophists, Protagoras believed that man is the criterion or the standard for everything: $\mathrm{He}$ is the standard for the things that exist and the standard for the things that do not exist; in other words, Plato firmly believes in the originality of spirit. For him, the soul is the most valuable possession of man. In his prayers, Plato says, O my beloved God, let me experience the inward beauty [2]. According to Plato, the highest good, or the bliss, of man includes the knowledge of God. However, euphoria, or prosperity, should be obtained through the pursuit of virtue, which is possible only if man tries to become similar to God.

We should become similar to God, as far as possible. It means that we should become just and honest through the assistance of wisdom. Anyone who desires to be loved by God, he should become similar to Him, as far as possible. Plato's ideal man is the person who seeks the entire wisdom, since wisdom comes from the Heaven, and therefore, it never loses its strength. According to Aristotle, man's felicity comes from his thinking, and from his ideas. Copplestone reports that Aristotle gives various arguments that the highest prosperity is the thinking, and that reason is man's greatest faculty, and that meditating is the greatest activity of the mind, and that prosperity depends on the employment of the mind. In other words, only through the application of the mind in the noblest issues can man find his euphoria. To Aristotle, the highest mode of knowledge is, therefore, God.

Therefore, man has got a high status in the Greek philosophy. Man's status, according to the Greek philosophers, and specifically according to Aristotle, is high, and his station is defined in terms of his meditation on God. Aristotle considers euphoria as something related to the inner states of thought, or the spirit, Moreover, Aristotle considers virtue as something leading to the achievement of balance, In other words, he considers virtue as a mediator for the creation of equilibrium among different aspects of human behavior and living [3].

\section{MAN ACCORDING TO MUSLIM THINKERS}

Muslim philosophers define the life on the basis of the Koran. They resort to the holy book to see whether the life is meaningful, goal- oriented, or else, futile.

"What, do you think that we created you in vain?" [4]: This 
rhetorical question in the Holy Koran states that God's deeds are wisely devised and that His actions are goal- oriented, and meaningful. Farabi believes that the existence of community is necessary for the perfection. He is, therefore, under the influence of Plato and Aristotle.

The ultimate goal towards which Farabi is walking is. Indeed, the achievement of euphoria. This euphoria according to him consists of some components, acting as pre-conditions. In his book the Acquisition of Euphoria, Farabi lists four components of prosperity in this world and in the Hereafter [5]:

- Theoretical virtues

- Virtues of thought

- Ethical virtues

- Practical Device

Elsewhere, he says that the main goal of ethics is the acquisition of euphoria. For him, the ultimate perfection is the good, and that the euphoria is the highest good. The more man tries to reach the good, the more he gains euphoria.

Avicenna believes in the process of perfection for creatures and in the ascending arc from inanimate to vegetables and animates and Jinn and humans in the front of an evolutionary process. He believes that man is located on the last point of life perfection in the material world, who possesses every accomplishment found among the lower creatures, in addition to a thinking faculty, or as he terms it, a thinking soul when the thinking soul comes to existence in him, and after the serene temperament is added to the soul, the Holy spirit, or as he terms it, the pure Reason, comes to existence. Then, human goes the path of evolution again in order to make the soul more transparent. At this stage the forms of knowledge separate from the Active Mind, creating a degree of perfection experienced by Elders and prophets without a message from God.

After this stage, as his perfection increases, man reaches the station of Active Mind, and he receives messages from God. If man transcends in the station of messengers, he will reach the station of pure Angels and Active Minds. In the station of pure Minds, there are, of course, different degrees. These degrees can be materialized for man, ranging from mere materiality to pure spirituality. Any person may attain one of degrees of humanity, depending on his capability and aspiration, or depending on a Favor from God [6].

\section{ARISTOTLE'S VIEWPOINTS}

Different philosophers have defined euphoria in different ways. Some philosophers have presented a hedonistic interpretation, and some others have interpreted it in terms of internal virtues.

Hedonists believe that euphoria, the desirable good, is experienced through the sensual pleasures including happiness, craving, carelessness, etc., since they are the components of euphoria.

Pre-Aristotelian philosophers believe that euphoria can only be found in the perfection of soul. They maintain that euphoria is the realization of such virtues as wisdom, courage, chastity, justice, and so forth within the soul.

Aristotle considers euphoria as the virtuous living, or as the activities in accordance with virtues, or in accordance with the highest virtue, i.e., the theoretical wisdom.

In the field of ethics, Aristotle is extremely teleological. He believes that each action of man is, indeed, a step in the direction of a single purpose. This purpose is the ultimate good, and the highest good, or rather, the very good itself. In other words, euphoria is good in nature, and that it is innately good. Humans have been created in a way that they seek euphoria. Aristotle also says that euphoria, as the final goal, has two characteristics: First, it is innately perfect and impeccable. Second, it is unique and for itself. It is sought not for anything else, since it is reasonable to seek a thing for the sake of euphoria, and to seek euphoria for the sake of itself, we must have the justification for the belief that there is no good thing than euphoria; otherwise, why shouldn't another good be the ultimate purpose, besides euphoria?

Aristotle gives a criterion by which euphoria can be understood [7]. He explains that if something, say X, is good, and we call it euphoria, but later, we learn that there is something else, say $\mathrm{Y}$, which is also good in a way that $\mathrm{X}+\mathrm{Y}$ is better than $\mathrm{X}$, it will be clear that $\mathrm{X}$ is not the euphoria. This criterion for euphoria does not specify the nature and the type of life that brings about euphoria.

Aristotle believes, by focusing on man's functions and roles, we can present a more definition of euphoria. As man is necessarily a reasonable creature, he must be, functionally, guided through reason. The appropriate life for man, therefore, is a life which can be directed by the practical reason and in accordance with virtue: only reason, and virtue, can cause man to prosper, i.e., to realize the perfection of his soul.

Aristotle takes euphoria as the virtuous life or as the activities in accordance with virtues or as the greatest virtue, i.e., the theoretical wisdom [8].

In many respects, Muslim philosophers' interpretations of euphoria are consistent with Aristotle's interpretation, although there are differences in their analyses of euphoria, which stem from religious influence.

Due to the relationship between euphoria and the spiritual transcendence, philosophers usually try to first explicate the spirit, or soul, and its capabilities. In order to understand euphoria, it is necessary to understand the soul, and thereby the mankind, so that the key to euphoria, or prosperity, as Muslims call it, can be understood, since the soul is indeed the key to euphoria, and the means by which man is able to acquire virtues, and since it is the internalized reservoir of human higher values [9].

Aristotle maintains that there are two kinds of virtue: rational virtues and moral virtues. Rational virtues include practical wisdom or reason, and moral virtues include justice, freedom, bravery, courage, and so forth. They need to be guided by the practical reason. He concludes that euphoria is a durable or permanent action in accordance whit both moral and rational virtues. Accordingly, the virtue lies somewhere between these two extremes.

Aristotle states that it is not enough for the virtue to just recognize good and evil, He believes that wisdom and virtue influence each other, and that wrongdoing is caused by dominant desires. Aristotle holds that pleasure is not the ultimate purpose, i.e., euphoria. He explains that pleasure functions as a prerequisite to euphoria. He reminds us that a 
prerequisite to something is not the same as the thing itself. The value of pleasure depends on the practical value of pleasure, and not every pleasure causes a single feeling. Each pleasure evokes a specific feeling. Aristotle believes that some pleasures are evil, which bring about evil. A life on the basis of pleasure, in which reason does not play a leading role, is not appropriate for a reasonable creature.

\section{A. Nature of Euphoria According to Aristotle}

In a broad sense, the definition of euphoria, or its nature, is a variable of the meaning of life. In order to define euphoria, one has to interpret life. Ethical systems can fall into two main categories:

- Ethical systems of this world

- Ethical systems of Hereafter

In other words, there are two distinct ethical systems: earthly systems, and heavenly systems. The first systems focus on euphoria, and life, in this world, and the second systems see the present life as a preamble to the life hereafter. According to the Earth ethics, which emerged when Bacon and Descartes presented their ideas in the Modern era, euphoria in this world is the goal. It tries to provide recipes for euphoria in the present life, and the ways to euphoria are appropriate for the present world.

On the nature of euphoria, Aristotle says that every science, or rather, every knowledge focuses on a sort of utility, or goodness. Goodness is the purpose or goal of every action. Now, there are different actions, and hence- different purposes or goals. Since some actions are subordinate to some others, and since some actions include some others, the purposes of actions are overlapping. Therefore, there is a range of purposes and goals which go on endlessly. If so, man's actions will be in vain. Therefore, this range has to end in a certain purpose, which is man's highest good. Man's highest good, as the highest purpose, is the theme of politics, because the science of politics focuses on man's highest good, presented to the human community as the true euphoria.

Concerning the union of ethics and politics, as a single science responsible for studying the nature of euphoria, Aristotle maintains that every mode of knowledge as a rational action or movement focuses are no exceptions. Ethics and politics are one. However, it is called ethics when it focuses on the good of individuals, and it is called politics when it focuses on the good of society. The good which is studied by this union, i.e. the highest good, is euphoria. Concerning what euphoria is, and what man must do in order to prosper, Aristotle inductively states that everyone agrees that euphoria is man's highest good, yet they disagree about the nature and about the definition of euphoria: soma people think that euphoria consists of the pursuit of pleasure, others think that it consists of wealth, and of nobility, and some others think that euphoria comes from good health [7].

\section{B. Virtue, and Types of Virtues According to Aristotle}

Virtue is an internalization that makes man good, and makes his actions good. This can happen when man's actions and interactions are within limits.

Aristotle first divides virtue into two types: rational virtue and ethical virtue.

Rational Virtue: This type of virtue comes about through learning. It needs time and experience to develop.

Ethical virtue: This type of virtue is the result of habits. It does not result from nature, because no natural creature may have acquired a habit contrary to their nature.

Naturally, we have the capability to nature our virtues, yet it is through habits that we may be able to make them perfect. At first, we have our natural abilities potentially, but we can actualize them later through our actions. Senses confirm this fact.

We acquire our virtues through practice. In other words, through acting on the basis of material and spiritual virtues, we can acquire them.

Aristotle believes that virtue is an internalization of good deeds, thereby changing man into righteousness, so that his actions and interactions will be within limits [10].

Although being within limits is a virtue, and going to extremes is evil, not every action (and every interaction) is considered to be within limits. For example, actions such as treason, shamelessness, rancor, murder, etc. are always considered as evil or corruption; we cannot consider any moderation for such actions.

Aristtotle's theory of being within limits has been criticized, to be sure. For example, it has been said that the extreme point of learning is the knowledge of indefiniteness, and the opposite extreme is the utter ignorance. Therefore, how can we find any moderation, or as critics put it, limits? Moreover, can we say that the indefinite knowledge is bad, because it is going to extremes?

In addition to setting standards for virtue, Aristotle has addressed virtues in details. He has studied such ethical concepts as courage, bravery, chastity, generosity, bounty, etc. as well as the opposites of these concepts, as follows:

Bravery lies between the extremes of boldness and fear, generosity is between wastefulness and stinginess. Between the extreme of boasting and shyness lies truthfulness. Modesty lies between baseness and arrogance. Receptiveness is between funniness and sternness. Flexibility lies between the extremes of surrender and despotism. Dignity is between ambition and lowness, and so forth.

Aristotle believes that euphoria and virtue are not the same. There is, rather, a causal relationship between them. In other words, they are causes and effects: virtues cause euphoria; through practicing in accordance with virtues, one will reach euphoria [11].

\section{Characteristics of Euphoria According to Aristotle}

Aristotle believes that euphoria has two main characteristics: First, euphoria is innately desirable. In other words, we seek euphoria for the sake of euphoria. Second, euphoria is independently good by itself. In other words, euphoria does not need any entity or force. This utter independence is but pure perfection. Therefore, man's euphoria is innately desired by him, and it is innately independent. Accordingly, euphoria is the one God, and no other truths. The prosperous man is moving towards the pure reason, i.e. the closer to God, the closer to euphoria.

Aristotle maintains that every sensual and/ or rational virtue aims at preparing man to achieve the status of thoughtfulness which is, indeed, the action of God. By thinking, man tries to be similar to the essence of God who is 
the absolute thinking [12].

Aristotle says that thinking is the differentiating element that separates man from other animals, a fact that causes him to survive because man's material elements are mortal.

It is the euphoria of man's soul that makes him immortal, and he must be good- doing, and indifferent to the worldly matters in order to achieve euphoria [13].

\section{EUPHORIA ACCORDING TO AVICENNA}

Avicenna defines euphoria as the ideal in essence and the end in essence [14]. Religious philosophers classify the end into two categories: the end in essence and the end in mediation. By the end in mediations, they mean an end which acts as a mediator for other ends. For example, education for knowledge is an end in mediation. In contrast, the end in essence is an end which is valuable in itself: it is not a means for an end; it is an end in itself, and it is the best and greatest end. Avicenna, therefore, maintains that no end in essence is higher and more perfect than euphoria. In his nature, man seeks goodness.

Innately, he has an orientation towards euphoria, or something that creates euphoria. This orientation is so strong that, one can claim, nothing is man's ideal end in essence save euphoria.

Avicenna maintains that euphoria is man's ideal end in essence. He explains that if we assume that euphoria is sought as a means for other things, we will make the mistake of believing that the first ideal end is not euphoria, and that euphoria is the second end. However, we have already considered euphoria to be the first end. It is, therefore, contrary to our assumption. If, presumably, the second end is not euphoria, and it is a means for the third end, the process will continue endlessly, and we will never have a final end, which is impossible.

We can conclude, therefore, that euphoria is the ideal end in essence: it is sought for its own sake; it is not an ideal for other things, as a means for another end [14].

Unlike Aristotle, who defines euphoria as the end in itself, or in essence, but replaces the end with the goodness in the final run, Avicenna considers euphoria to be only on the basis of ideation.

In his different works, Avicenna has pointed to various types of euphoria, including the intellectual pleasures and the physical or sensual pleasures; he believes that the intellectual pleasures are well superior to the physical pleasures. Compared to sensual or carnal pleasures, the intellectual pleasures are higher both quantitatively and qualitatively. Intellectual pleasures are superior to carnal, or animal, pleasures qualitatively in that the reason is able to understand the deep nature of truth as it is really perceived; the non-intellectual perceptions can understand only the superficial quality of things. For this reason, Avicenna has stated that "intellectual perception is free from shortcomings and defects when it comes to the deep nature of things, while sensual perceptions are full of shortcomings and contaminations".

The superiority of intellectual pleasure to the sensual, animal pleasure in terms of quantity stems from the fact that the number of advantages of reasonable things is infinite, while the perceptions of senses are limited and finite. If the perceptions of senses are numerous, the differences may stem from their quality and intensity. We can say, for example, that the comprehension of the existence in essence, which is a perception abstract of materialistic existence, and the pleasure resulting from it, is not comparable to the pleasure coming from the eating of a delicious food.

For three reasons, the intellectual pleasure is superior to the sensual pleasure:

1) The sensual pleasure is changeable, alterable, and unstable, while the intellectual pleasure is durable and unchanging.

2) Intellectual pleasures result from the deep perception of things and phenomena, whereas sensual pleasures come from a superficial perception of appearances.

3) Sensual pleasures are limited and finite whereas intellectual pleasures are unlimited and infinite [15].

In another classification, Avicenna divides euphoria into absolute and limited types of euphoria. He believes that neither absolute euphoria nor absolute adversity can be realized in this world, since everybody thinks that he is the wisest man in the world. If it is the case, there cannot be any adversity, any euphoria, any good, and any evil in an absolute manner [15].

Every man has the potentiality to reach euphoria, or else adversity, the good or the evil, and we may not call it euphoria, adversity, good, or bad: potentials do not exist as of now; potential euphoria is not the real euphoria, and potential adversity is not the real adversity, and so forth. Now, it is man who can develop his potentiality on the basis of his will: man is prosperous, or else wretched, according to his aspirations [16]. We cannot say, to be sure, man becomes absolutely prosperous only through developing the good potentiality of his, nor can he become absolutely wretched only through developing his evil potentiality, in this world.

Avicenna is, to some extent, influenced by Aristotle; like Aristotle, he classifies the virtues into two types: temperamental virtues and viable virtues. Temperamental virtues, in turn, are subdivided into three types: wisdom, courage, and chastity. When they are integrated, the result will be justice. By viable virtues, Avicenna means the practical knowledge or philosophy, as contrasted to the theoretical wisdom [17].

\section{Relationship between Perfection and Euphoria According to Avicenna}

In philosophy, perfection means the actualization of potentiality: a thing has developed to its existential perfection when it actualizes its potentiality. Peripatetic philosophers believe that man's euphoria is obtained with the perfection of his theoretical faculty and his practical faculty. Philosophy is a means for the achievement of euphoria. As man's goal in life is to obtain euphoria indeed, and as euphoria can be obtained only through knowledge because knowledge is the light and ignorance is the darkness, philosophy becomes the best means. For these philosophers, reasoning is possible only through resort to the active mind and through the absorption in the intuition of celestial world [18].

All other things are among man's ideal only if they contribute to this end.

In the Islamic philosophy, the concept of euphoria is 
associated with such words as perfection, good, and pleasure. Avicenna believes that every existent seeks pleasure, and that the lay, that is, the illiterate people wrongly think that sensual pleasures are the strongest pleasures. They do not know that the strongest pleasure comes from strong perceptions. He says that a wise person should not limit himself to sensual pleasures, as animals do.

Concerning intellectual pleasures, Avicenna states that what reason considers being good is sometimes the truth, and sometimes it is the beauty [ibid 340:3, 1403].

I think Avicenna says that there are two kinds of intellectual pleasure: one comes from the knowledge of truth, and the other is the knowledge of beauty.

Avicenna refers to euphoria as 'the perfection of rational soul'. Therefore, he thinks that the final euphoria is to observe the existence of truth. He then says that the rational soul can have the power of rational observations: " euphoria is the entire separation from the consideration of tangibles, the confinement of sight to the glory of the truth the almighty, and the intellectual studying of the truth. Through this consideration, a form of the entire being will be reflected in the rational soul. The soul will see the entire being, while beholding the existence of the almighty truth intellectually without any separation." [ibid. 60, 1980]

Accordingly, the greatest happiness, and the highest prosperity, the euphoria, is the connection with the necessary being, although the lay think that euphoria is something else.

Some Avicenna commentators, and some scholars of Avicenna, think that Avicenna's euphoria is the being itself, or the comprehension of being, and since there are different beings, man's euphoria consists of different stages as if on the basis of a hierarchy, depending on man's understanding of being, and that the noblest being is the being of almighty truth, and consequently, the person who has knowledge of the truth has obtained the most perfect euphoria [18].

If we accept that euphoria, according to Avicenna, consists of different stages in a hierarchical order, one may ask the following question: what is the highest stage of euphoria?

In his many writings, Avicenna has presented different answers to the question. In fact, he has presented the farthest euphoria in different forms:

In some works, he says that man's soul has different faculties, and one of them is the faculty of reason. This faculty has a potential capability. If the capability develops into actuality, it will obtain its euphoria, which is the perfection. In man's faculty of reason, there exists the ability to meditate on the universe of being, and hence, on every stage of existence. In other words, man is potentially able to meditate on the existence of almighty God and understand His attributes and His oneness. Then, in the second stage, man will be able to demonstrate his understanding through reasoning. In the third stage, he will be able to meditate on other beings down to the lowest order. When man's soul reaches this stage, he will become an understanding microcosm similar to the objective world on a small scale. Avicenna believes that every good existing in the world of being comes from the origin general, that is, the almighty. Then, the good goes to the valuable essence, that is, the mind which is the origin of pious souls. In the next stages, the good comes to the celestial bodies on the basis of laws of astronomy ... finally, an understanding microcosm similar to the existing world, but on a small scale, will emerge [19].

In his other works, Avicenna says that the highest stage of man's euphoria is his similarity to the active mind: human souls are distinct from each other in terms of their access to knowledge or perfection or other virtues. Some souls are in a low status, and others are in a high status. The latter are the prophets of God. In terms of knowledge and perfection, man can achieve a position similar to that of the active mind. This position is the perfection of euphoria. Else- where, Avicenna thinks that the farthest stage of euphoria stems from the separation of spirit from the body. On the resurrection day when man is free from the adversity and troubles of this material world, he obtains euphoria because he spends eternity with happiness and enjoyment [20].

Avicenna considers the active mind to be the cause of man. He maintains that man is not able to achieve the active mind because the cause is superior to the effect. Man is able, however, to take steps towards the active mind and make him similar to it.

In his book 'the origin and the resurrection' , Avicenna states that the final euphoria of soul comes about upon the abstraction from the material world, and when the soul achieves the perfect abstraction, that is, the reason, it has achieved its perfection.

Aristotle, also, thinks that euphoria is in stages. Therefore, depending on the amount of his efforts during lifetime, man can increase his euphoria. Step by step, he can go through the degrees of euphoria in order to reach the highest stage of euphoria. In this stage, man will be the fully prosperous man, or the perfect Prospero. This may happen even in this world [21].

Unlike Aristotle, Avicenna believes that the body serves as an obstacle in the way of soul: it veils the perception of spiritual and true pleasures. For this reason, Avicenna likens the conditions of soul before the separation from the body to those of a sick person who cannot feel the taste of foods. When he recovers from his illness, he can enjoy eating delicious foods. After separation from the body, soul immediately finds out that it feels pleasures other than the sensual and animal pleasures the body needs.

The new pleasures are higher and nobler than the former pleasures, and this is the true euphoria [21].

\section{CONCLUSION}

According to Aristotle, euphoria is not the same as virtue. The relationship of virtue and euphoria is a relationship on the basis of order. One is the first, and the other is the last. In other words, they have a cause-effect relationship. By acting on the basis of virtues, man attains euphoria.

According to Aristotle, euphoria is innately ideal: we seek euphoria for the sake of euphoria. It must be innately independent, needing no other entity. It is man's ideal good in itself. Since man euphoria is innately desirable and innately independent, the true euphoria is the one God, and not another truth. The prosperous man, therefore, is moving towards the pure reason, i.e.

God the Almighty. Like Aristotle, Mulla Sadra believes that man's euphoria is the same as the attainment of his 
ultimate goal and true perfection, i.e. nearness to God, or as Aristotle puts it, the absolute good, because there is no other perfection or good than the Divine Holy Presence. Whenever man reaches that great station, his soul will experience happiness incomparable to any happiness.

Attainment of perfection is optional rather than innate: Each person has to attain perfection through his voluntary actions wittingly.

Through education, learning, and nurture, man is able to reach his ultimate purpose, i.e. his prosperity and euphoria in two dimensions of wisdom: the theoretical dimension, and the practical dimension.

If man wants to attain euphoria, he must get rid of two kinds of veils: the internal veils, and the external veils. The internal veil consists of the shortcomings of soul. It can be removed in the light of Active Reason. The external veil consists of the soul's involvements with sensual faculties, anyway, if man is able to do away with these two kinds of veils, everything will be revealed to him, and everything will become apparent for him.

Avicenna thinks that euphoria is something true and hence- belonging to the hereafter, which cannot be attained in this world. Aristotle, however, believes that euphoria can be obtained in this world.

Both Avicenna and Aristotle think that euphoria has different stages.

Avicenna believes in the all- embracing euphoria. He maintains that man is not a one- dimensional creature. He is, rather, a creature consisting of two dimensions: physical and spiritual. Avicenna, therefore, believes that man should pay attention to his both physical and spiritual tendencies as well as capabilities. He should try to satisfy the needs of his two dimensions.

\section{ACKNOWLEDGMENT}

The author would like to thanks the Khorram abad Islamic Azad University for helping and support.

\section{REFERENCES}

[1] C. Friedrich, The History of Philosophy, Translated into Farsi by seyyed Jalal- din Mojtabavi, 2nd ed. Soroush publication, 1991.

[2] K. Anthomy, Aristotle on the Perfect Life, Oxford, 1992.
[3] J. L. Vrmson, Aristotles Ethics, Oxford, 1988.

[4] The Holy Koran, ch. 23, pp. 115.

[5] F. Majid, Ethical Theoeies in Islam-Netherlands, Brill, 1991.

[6] Avecina, Bou-Ali Suggestions and Punishments, Mohaghegh- e- Tousi and Ghot- bed- din- Razi,Ghom, Nashrol-Balaghah, Ed, 2001.

[7] Aristotle, The Nicomachean Ethics, Translated by Aboulghasem Hossaini, Tehran University, 2002.

[8] R. David, Aristotle, Tehran, Routledge, 1988.

[9] Banouy-e-Isfahani, Ethics and the path of Euphoria, Translated and adapted from Ibin- Meskevay,Tehran, Muslim Women movement publication, 1981.

[10] V. Mary, The Philosophy of Ethics, Translated by Aboughasem Ghanee, Tehran,Boustan ketab publication, 2nd ed, 2009

[11] C. Friedrich, The History of Philosophy, Translated into Farsi by seyyed Jalal- din Mojtabavi, Tehran, publication 2nd ed.

[12] H. Amoli, Avicenna's Sheff-ol- Elahiat, an Introduction, Ghom, Islamic propagation office, 1418 A.H.

[13] H. Abdollah, "Epistle concerning Euphoria," Collected Epistles of shaikh-o- Rais Abu Ali ibn sina, Ghom, Bidar publications, 1400 A.H.

[14] "Association of Avicenna studies, 'Avicenna's Differences of soul'," Association of Avicenna Studies, Ghom, 1999.

[15] Office of Islamic philosophy, Avicenna's Epistle Concerning Love, Tehran, 1999.

[16] M. Bidarfar, Avicenna's Discussions, Annotatae, Ghom, Bidar Publications, 1992.

[17] A. Musa, A Reading of Avicenna's Epistle Concerning the Soul, Hamedan, Bu Ali University Press, 2003.

[18] M. Mottahari, Bahmanyar's Acquisition, Annotated, Tehran University Press, 2007.

[19] H. Malikshahi, Collected Essays on Avicenna's Isharat and Tambihat along with Khajah Nassir's Commentary, Tehran, Daftar Nashr-eketab, 1403 A.H

[20] H. bin Abbdollah, Epistle Concerning the Soul and its Resurrection, compiled by office of Islamic philosophy, Tehran, 1999.

[21] M. Minavi and A. Haydari, Ethics of Khaja Nassir, Tehran, Tehran University Press, 1988.

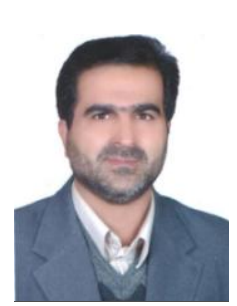

Hojjatollah Raftari is a Ph.D. candidate in philosophy. He is a lecturer at the faculty of humanity science, khorramabad Islamic Azad University, Iran. He obtained his B.Sc in theology from Khorramabad Islamic Azad University, and M.Sc in philosophy and theology from Karaj Islamic Azad University, Iran. He is currently a Ph.D. student at the tehran institute science and research, Iran. Hojjatollah Raftari's field of interest is comparative philosophy and its aspects in the world. He has produced some books, technical papers, and journal papers. 